\title{
EFFECT OF FINANCIAL GLOBALIZATION ON DEVELOPING COUNTRIES
}

\author{
Nikhil Purohit \\ BBA Student-Jain University-Center for Management Studies, Bangalore, India \\ Dhwani Adesara \\ BBA Student-Jain University-Center for Management Studies, Bangalore, India \\ Swati Kedia \\ BBA Student-Jain University-Center for Management Studies, Bangalore, India
}

\section{Prof Abhishek Venkteshwar}

Assistant Professor--Jain University-Center for Management Studies, Bangalore, India

\begin{abstract}
Research in the field of globalization has become a dynamic area. This research paper provides the effects of financial globalization for developing economies. It mainly focuses on the analysis about how the developing countries can achieve the benefits and control the risk of financial globalization. This research paper also comes to a conclusion about the rapidly growing, positive support for financial globalization. This article hopes to provide a better perspective to the reader.
\end{abstract}

Key word: financial globalization, developing countries economy.

Cite this Article: Nikhil Purohit, Dhwani Adesara, Swati Kedia and Prof Abhishek Venkteshwar, Effect of Financial Globalization on Developing Countries, International Journal of Management, 10 (4), 2019, pp. 19-23. http://iaeme.com/Home/issue/IJM?Volume=10\&Issue $=4$

\section{INTRODUCTION}

Financial globalization is integration of all countries financial markets of the world into one big market. There is some relationship between the financial globalization and economic growth. the beneficial effects of financial globalization can be easily detected if there is an absorptive capacity of developing countries. Many countries ( china or India ) are conventionally applying or using FG to attract sophisticated investors and other financial institution which fosters the development of domestic financial markets .More liquid markets are expected to attract foreign inflows and large investors that require a minimum trading scale. FG and international risk sharing. In past theoretical research studies, the implications about financial integration countries with greater FG should reduce consumption relative to output volatility through international risk sharing. In theory, one of the more important benefits of financial globalization comes by allowing more efficient international risk sharing in a country. 
However developing countries are becoming more connected to global finance. Their share of total foreign investment assets has risen from 8 percent to 14 percent in the past decade. China's rise in global finance is most notable; it rose from 16th place in 2005 to 8th in 2016. China's total stock of foreign bank lending, foreign direct investment, and portfolio equity and bond investments reached $\$ 3.4$ trillion in 2016, exceeding its $\$ 3.2$ trillion of central bank foreign reserve assets - a notable shift. A more stable global financial system is emerging, but there are still risks.

\section{LITERATURE REVIEW}

\subsection{Globalization}

Singh (2012) in his paper "Globalisation and Its Impact on Indian Economy" found that India needs to launch a 'second generation' of economic reforms, with a more human face, the reforms must be based on the long-term vision of transforming India into a global economic power in the next twenty to twenty-five years.

Sharma (2009) in his book "China and India in the Age of Globalisation" explored how the interplay of socio, historical, political and economic forces has transformed, India and China, once poor agrarian societies into economic powerhouse. In this book he examined the challenges that both countries face and what each must do to strike the balance between reaping opportunities and mitigating risks.

Pillania (2008) in his study “An Exploratory study of Indian Foreign Trade" studies various aspects of Indian foreign trade since 1949. He found that Indian foreign trade has progressed a lot over the last sixty years since independence and India lost its market share to other countries in 1950s and 1960s. The situation improved in 1970s and exports have finally picked up in post liberalization era in general and after 2002 in particular.

Singh (2007) in his study "Globalisation, Industrial Revolutions in India and China and Labor Markets in Advanced Countries: Implications for National and International Economic Policy", examines the impact on labor markets in advanced countries of the integration of the fast - growing countries, China and India. After his study he suggests that Globalisation has a small overall effect on output and employment in advanced countries. The paper concludes that current Globalisation cannot meet these twin objectives and that coordination and cooperation between nation states under alternative Globalisation are much the better way, if not the only way of realising these objectives.

Goyal (2006) in his paper "Impact of Globalisation on developing Countries (with special reference to India)" explores the contours of the on-going process of Globalisation Liberalization and privatization. Throughout this paper, there is an underlying focus on the impact of LPG on Indian economy. Various studies have been made to analyse different aspects of Indian foreign trade, but little has been done to study the impact of Globalisation on Indian foreign trade. Hence, present study proposes to study the effect of Globalisation, on India along with other untouched aspects of the Indian foreign trade.

Basu (2001), laidler (1995), Phelps (1998), has explained the effect of Globalisation on the perspective of health care services and its reforms. The effect of trade and education reforms is well defined by D. Sampath Kumar (2011), Karl P Opper (1995). Again, The Annual Survey of Industries [EPW Research Foundation 200] and Handbook of Statistics on Indian Economy [RBI 2001] are explaining the requirement of small industry as an effective part to measure the impact of Globalisation.

N R Bhanumurthy and Lokendra Kumawat(2018) in their paper " Financial Globalisation and Economic Growth in South Asia" found out that it is the domestic factors and domestic macroeconomic policies that are attracting more foreign capital. The reverse causation ap- pears 
to be weak, atleast in majority of countries in south asia. Such results could also support the dominant view in the literature, which suggests that capital account liberalization and output growth relationship follow a transition function: in the initial phase growth could attract foreign capital, while in the long run foreign capital could contribute to growth through both direct and indirect channels. But, it is most important to have better domestic fiscal and financial sector that could lead to better outcomes from financial globalisation.

Eduardo Levy-Yeyati and Tomas Williams in their paper Financial Globalization in Emerging Economies: Much Ado About Nothing? Have found out that -Perhaps the main take away from the previous empirical examination of Financial globalization is its most pedestrian finding: for all the market and media hype about the increasing globalization of emerging economies, financial globalization in the emerging world appears to have been vastly overstated. Rather than growing in the 1990s and 2000s as usually argued based on standard GDP ratios, de facto globalization have accompanied (and, to some extent, supported) a more secular process of financial deepening (in EM and elsewhere), temporarily slowed down by the recent global crisis. More precisely, once measured in a way that minimize the various biases that plagued the most popular empirical proxies, Financial globalization in Emerging markets looks rather stable, and well below advance country levels.

\section{OBSERVATION}

On completing an extensive secondary research and literature review, the following conclusions can be made.

- There is a direct relationship between Globalization and Finance impacting the Ecponomy.

- Financial Globalization has a positive influence on the Indian Economy.

\section{RESEARCH GAP}

Research has been conducted extensively on the relationship between globalization and Finance in developing nations, but there is not enough studies on the negative impact of globalization on Finance and that will be explored by me in my next article.

\section{CONCEPTUAL MODEL}

The Conceptual Model explains globalization affects and influences the Economy of developing countries both positively and negatively. 


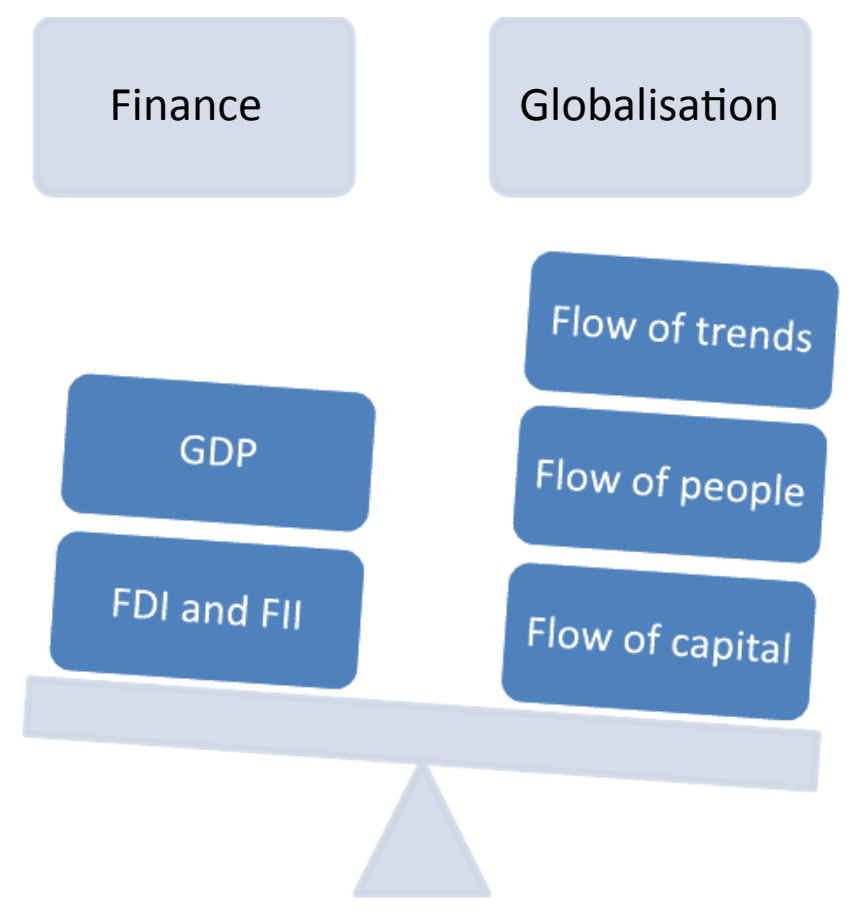

\section{CONCLUSION}

On doing an extensive Secondary Research and Literature Review about globalization and the economy of developing countries., it has been concluded that primary research on 7 businessmen of different countries will be conducted as a next step in order to test the correlation between globalization and Economy of those countries. This research aims at shifting the focus to more macroeconomic indicators that is influenced by globalizations.

\section{REFERENCES}

[1] Ahmad; M, Pervaiz, K \& muhammad, A, Factors Affecting the Students' Academic Performance. Journal of Educational Research , 13(1), 2010, 252

[2] Alexander B. Siegling, Adrian Furnham, and K. V. Petrides, Trait Emotional Intelligence and Personality: Gender-Invariant Linkages across Different Measures of the Big Five. Journal of Psychoeducational Assessment 2015, Vol. 33(1), 2015, pp 57-67

[3] Donald, et al, Personality, Emotional Intelligence and Exercise. Journal of health Psychology, 12 (6),2007, pp 937-948

[4] Downey, L, Fluid Intelligence, Personality, and Emotional Intelligence. Canadian Journal of School Psychology, 29(1), 2014, pp 40-53.

[5] Anshul Saini and Navpreet Soni, Role of Emotional Intelligence in Construction Industry: A Review. International Journal of Civil Engineering and Technology, 7(4), 2016, pp.339-344.

[6] A. Sathya and Dr. V. P. Velmurugan, Role of Emotional Intelligence in Leadership Behaviour- A Review. Journal of Management, 5(3), 2018, pp. 187-191.

[7] Ferrando M., Prieto M. D., Almeida L. S, Trait emotional intelligence and academic performance: Controlling for the effects of IQ, personality, and self-concept. Journal of Psychoeducational Assessment, 29, 2010, 150-159. 10.1177/0734282910374707

[8] Furnham, A., L. Forde and T. Cotter, Personality and intelligence. Personality and Individual Differences 24:2, 1998, pp 187- 192.

[9] Gallagher, S.A, Personality patterns of the gifted. Understanding our Gifted, 3, 1990, pp 1113 
[10] Goldberg, Lewis R., Journal of Personality and Social Psychology, Vol 59(6), 1990, pp 12161229

[11] Goleman, D, What makes a leader: Harvard Business Review, 2008

[12] Greenberg Jerald \& Baron Robert A, Behavior in Organizations. Ninth. ed. New Jersey: Pearson Education, Inc, 2008

[13] Hijazi, Syed Tahir and Naqvi, S.M.M. Raza, 'Factors Affecting Students' Performance: A Case of Private Colleges'. Bangladesh e-Journal of Sociology: Volume 3, Number 1, 2006

[14] Higson, H. \& Andrews, J., Education, Employment and Graduate Employability: Project Manual. Aston Centre for Research into Higher Education, Learning \& Management, Aston University, 2007

[15] Mr. Kunj Karia, Study of Emotional Intelligence and its Influence in Organizational Behaviour, International Journal of Advanced Research in Management (IJARM), Volume 5, Issue 4, July- August (2014), pp. 60-65

[16] Joyce G. Walsh-Portillo, "The Role of Emotional Intelligence in College Students' Success" , Florida International University, 2011

[17] Martha, k, Factors affecting academic performance of undergraduate students at Uganda Christian University. Educational management of Makerere university, 1(1), 2005

[18] Michael Harris, Human Resource Management: A Practical Approach. First. ed. Florida: Harcourt Brace \& Company, 1997

[19] Mushtaq, I \& nawaz khan, S, Factors Affecting Students' Academic Performance. Global Journal of Management and Business Research, 12(9), 2012.

[20] McCrae, R. R., \& Costa, P. T., Jr, A five-factor theory of personality. In L. A. Pervin \& O. P. Johns (Eds.), Handbook of personality theory and research New York: Guilford, 1999, pp. $139-153$

[21] N Ryckman, R, Theories of Personality. Belmont, CA: Thomson/Wadsworth, 2004

[22] Paul Kline, Extraversion, Neuroticism and Academic Performance among Ghanaian university students. British Journal of educational psychology volume 36, issue 1, 1966, pages $92-94$

[23] Petrides K. V., Vernon P. A., Schermer J. A.,Ligthart L.,Boomsma D. I., Veselka L., Relationships between trait emotional intelligence and the Big Five in the Netherlands. Personality and Individual Differences, 48, 2010, 906-910.10.1016/j.paid.2010.02.019

[24] Petrides K. V., Pita R., Kokkinaki F, The location of trait emotional intelligence in personality factor space. British Journal of Psychology, 98(Pt. 2), 2007, pp 273-289

[25] Salovey, P., Brackett, M., \& Mayer, J. (Eds.), Emotional intelligence: Key readings on the Mayer and Salovey model. New York: Dude, 2007

[26] Salovey, P., \& Mayer, J, Emotional intelligence. Imagination, Cognition, and Personality, 9, 1990, pp 185-211.

[27] Abhishek Venkteshwar and Dr Uma Warrier, The Effect of Birth order in the Emotional Intelligence of Net Generation Students. International Journal of Management, 8 (6), 2017, pp. 69-75

[28] Stephen P Robbins, Organization Behavior, 9th edition, Pearson Education Asia, 2001

[29] Shipley, L, Jackson, M \& Segrest, S, The effects of emotional intelligence, age, work experience and academic performance. Research in Higher Education Journal ,9, 2010, pp $1-18$

[30] Weinberger, L, Emotional Intelligence: Its connection to HRD theory and practice. Human Resource Development Review, 1(2), 2002, pp 215-243. 